\title{
BMJ Global Health How (not) to write about global health
}

\author{
Desmond T Jumbam
}

To cite: Jumbam DT. How (not) to write about global health. BMJ Global Health 2020;5:e003164. doi:10.1136/ bmjgh-2020-003164

Received 15 June 2020 Revised 18 June 2020 Accepted 20 June 2020
Check for updates

(c) Author(s) (or their employer(s)) 2020. Re-use permitted under CC BY-NC. No commercial re-use. See rights and permissions. Published by BMJ.

Accra, Greater Accra Region, Ghana

Correspondence to Desmond T Jumbam; desmond.jumbam@gmail.com
There has been much talk recently in $B M J$ Global Health, in other journals, and on social media platforms, about equity in global health research. But there has been little guidance on how to write about global health in a way that advances equity and justice. Inspired by a famous satirical article by the Kenyan author Binyavanga Wainaina, I present some guidelines for how (not) to write about global health. ${ }^{1}$

It is frequently said that buy-in from local stakeholders is essential for the success of any global health project. Without local buyin, your project is likely not to be adopted by the community and be sustainable. In order to ensure that your project has the buy-in of the community, set up a 1- to 2-day workshop with community members to get their input on the project for which you already have funding and a protocol. As long as this workshop is held, and you mention it in your final write-up, it will be clear to your readers that you were able to obtain the buy-in of the community. Do not pay too much attention to what is discussed at the workshop; you already understand the issues and know exactly what the community needs. Plus, you already have funding for this particular project, and it is unlikely that the project will change significantly based on the actual needs expressed at this workshop.

Let sustainability worry about itself when the time comes. Your main task at hand is to develop and execute your project successfully (by your standards), write up the results and publish your manuscript. You need to meet those grant deadlines! You can worry about sustainability after the project is complete or better yet let somebody else worry about it.

Do not expend too much energy to find true collaborators on the ground from the very beginning. This can be time-consuming, and you have grant application deadlines to meet. Design the project and secure the funding first. That is the most important thing. Without funding, there will be no project. After the funding is obtained, then and only then should you seek out the buy-in of your local counterparts.
One week in a country or community is a significant experience and exposure to the intricacies of a particular culture for you to be able to write about that country or community's problems and propose solutions. With 1 week on the ground, you'll get the general idea. Lots of poverty and death, helpless people, corrupt national or local governments, something about colonialism, and oh yes, weak health systems. You get the idea.

Do not spend too much time studying the historical, cultural, anthropological, political and sociological contexts. Don't bother with trying to understand the complex intricacies and relationships between these and health. This will take too much time and will just delay the good work that you can do to help the country or community. Engaging too deeply with context will also delay the writing process. In any case, you are primarily a global health practitioner and not a historian or anthropologist.

You must not take that week you spent on the ground for granted. This, combined with the numerous articles and books that you have read, will give you sufficient expertise to write knowledgeably on your global health issue in that particular country or community.

When you write, do not overstate the historical and current efforts of local researchers, clinicians, public health practitioners, community groups and other individuals and groups on the ground. This can detract from your key message and take up valuable space in your manuscript. Do not bother using or acknowledging local knowledge. Write as if for an external audience; the foreign gaze. Also, do not cite the publications of local researchers, seeing that they are in predatory and local journals. Remember, whatever is not published in high impact journals never happened.

If you have already advanced far along on a manuscript and realise that you have none or too few local authors on your paper and are likely to be tarred and feathered on Twitter for lack of author diversity, you can always reach out to that acquaintance you met once on your 1-week trip. Invite them to 
be a co-author on the paper and be sure to emphasise how much you value their input in your email to them. They'll appreciate that. However, do not give them any major authorship positions on the paper, definitely not first, second or last author positions. In all fairness, they have not contributed enough to warrant any of these esteemed positions, but they will thankfully avert any Twitter outrage coming your way.

The acknowledgement section is a great resource. It is where you recognise all the significant contributions of your local partners. There is that one great person who has been your man or woman on the ground; they helped you gain access to the country or community, helped you to refine your research question, find participants and even helped you to make sense of your findings. Be sure to acknowledge their contributions effusively. Mention all that they did to help you and your research. But do not name them as co-author. Save the authorship positions for those who have done the 'real' work on the project.

There is always a silver lining, no matter how seemingly little impact your results indicate that your project has had. With some extra sophisticated analysis and a few twists and turns, you will find that silver lining. It is never a good idea to frustrate your funders. Where will you get more money to conduct other potentially impactful global health projects? It will certainly not help in getting you that professorship position that you so desperately want.

And yes, your study in one small community in remote Zimbabwe can be generalised to the entire country and even to the mostly homogeneous, if large, African continent. Be sure to emphasise this in the discussion section. Show how impactful your project and findings could be and recommend that your intervention be scaled up in all other low-income and middle-income countries, seeing that they all have similar needs.
Never forget to include the old African proverb "if you want to go fast, walk alone. If you want to go far, walk together" or the Chinese proverb "Give a man a fish, and you feed him for a day, teach a man to fish and feed him for a lifetime." How else will your readers know yours is a global health paper? It will also show that you have taken the time to understand local customs and have connected with the community on a deep level.

If you follow these guidelines, you are sure to become a prolific writer and successful global health researcher. But remember to train those coming behind, your research assistants and $\mathrm{PhD}$ students, to do just the same if they want to become successful like you.

Twitter Desmond T Jumbam @desmondtanko

Contributors DTJ conceived and wrote this manuscript.

Funding The authors have not declared a specific grant for this research from any funding agency in the public, commercial or not-for-profit sectors.

Competing interests None declared.

Patient consent for publication Not required.

Provenance and peer review Not commissioned; internally peer reviewed.

Data availability statement There are no data in this work.

Open access This is an open access article distributed in accordance with the Creative Commons Attribution Non Commercial (CC BY-NC 4.0) license, which permits others to distribute, remix, adapt, build upon this work non-commercially, and license their derivative works on different terms, provided the original work is properly cited, appropriate credit is given, any changes made indicated, and the use is non-commercial. See: http://creativecommons.org/licenses/by-nc/4.0/.

\section{ORCID iD}

Desmond T Jumbam http://orcid.org/0000-0002-3062-2519

\section{REFERENCE}

1 Wainaina B. How to write about Africa, 2005. Available: https://granta. com/how-to-write-about-africa/ 